This is a post-print version of an article published in:

Audet, P., \& Charest, C. (2007). Heavy metal phytoremediation from a meta-analytical perspective. Environmental Pollution, 147(1), 231-237. doi: 10.1016/j.envpol.2006.08.011. 


\title{
Heavy metal phytoremediation from a meta-analytical perspective.
}

\author{
Patrick Audet \& Christiane Charest
}

Ottawa-Carleton Institute of Biology

Department of Biology

University of Ottawa

30 Marie-Curie St.

Ottawa, ON, K1N 6N5, Canada

E-mail: $\quad$ ccharest@ science.uottawa.ca (corresponding author) paude086@uottawa.ca

Tel: (613) 562-5800 Ext.6359

Fax: (613) 562-5486 
$1 \quad$ Heavy metal phytoremediation from a meta-analytical perspective. ABSTRACT

We conducted a literature survey and correlated heavy metal (HM) uptake and plant growth factors from published data to estimate the effectiveness of phytoextraction. The

6 indicators of the actual plant HM uptake showed positive correlations with soil-HM

7 concentrations, while the relative plant HM uptake showed negative correlations. Plant growth

8 was negatively correlated with both the plant and soil-HM concentrations. These significant

9 relationships were found for the majority of $\mathrm{HM}$ tested (e.g. $\mathrm{Zn}, \mathrm{Cd}, \mathrm{Pb}, \mathrm{Cu}, \mathrm{Cr}$, and $\mathrm{Fe}$ ) with a

10 few exceptions (e.g. Ni, Co, and Mn). After fitting the correlation coefficients, the highest

11 proportion of variance among the studies was mainly due to the experimental parameters or the

12 plant species. When the metabolic costs of HM uptake are taken into account, the

13 phytoextraction appears to be less effective beyond critical HM concentrations. Despite these

14 constraints, it is emphasized that HM phytoextraction can play an important role in

15 bioremediation.

16

“Capsule": This meta-analytical approach has revealed a compromise between growth and HM uptake when plants are subjected to toxic soil-HM levels.

20 Key words: Bioconcentration factor; Specific extraction yield; Tolerance index. 


\section{INTRODUCTION}

Phytoremediation is defined as the use of plants to remove pollutants from the environment (Cunningham et al. 1995; Salt et al. 1998). Inorganic pollutants, such as plant trace elements (e.g. $\mathrm{Cr}, \mathrm{Cu}, \mathrm{Fe}, \mathrm{Mn}, \mathrm{Ni}$, and $\mathrm{Zn}$ ) and non-essential elements (e.g. $\mathrm{Cd}, \mathrm{Co}$, and $\mathrm{Pb}$ ), have been shown to be more difficult to remediate from contaminated soils as they cannot be degraded (Pilon-Smits 2005). Still, plants have been shown to take up and sequester heavy metals (HM) in roots and/or shoots and, therefore, to significantly contribute to their removal from the environment through a mechanism of phytoextraction. This mechanism occurs despite important growth challenges, including $\mathrm{HM}$ toxicity, changes to soil $\mathrm{pH}$, and mineral imbalances.

For phytoextraction to be effective plants must take up HM from the soil, tolerate high plant or soil-HM levels, and produce sufficient harvestable biomass (Chaney et al. 1997; Meagher 2000; Pilon-Smits 2005; Salt et al. 1995, 1998). Using a meta-analytical approach, our objectives were (1) to describe the relationship between the levels of soil-HM and actual or relative plant HM uptake, (2) to describe the relationship between plant growth and plant HM uptake, and (3) to evaluate whether these relationships are the same for all the HM selected. Thus, we have tested the hypothesis that HM phytoextraction is an effective means of phytoremediation for highly polluted environments, using meta-analysis as a useful and meaningful approach for summarizing relationships from multiple studies (Lipsey and Wilson 2001). From the current body of phytoremediation literature, we have quantitatively evaluated the key plant physiological relationships influencing the effectiveness of HM phytoextraction and have detected, with high statistical power, broad-scale trends which have been underestimated by conventional or qualitative review analyses. 


\section{$319 \quad$ 2. METHODS}

\section{$320 \quad$ 2.1. Meta-analysis}

321 In this meta-analytical study, based on the methods of Hedges \& Olkin (1985) and Lipsey

$322 \&$ Wilson (2001), we have tested the correlations between (1) the soil-HM concentration with

323 actual or relative plant HM uptake and (2) the plant growth with actual plant HM uptake or soil-

324 HM concentration, using combined results from multiple studies. The studies from which data

325 were used have been selected through searching of library journal directories and online

326 academic literature networks. In total, 36 articles were selected for having studied herbaceous

327 plants and measured biomass and HM uptake, whether under laboratory or field conditions. All

328 the HM with the soil concentration ranges and the 50 different plant species included in our

329 study are appended (Supplementary Data). The distinguishing features required for inclusion in

330 our analyses were that the soil mineral composition be described and the data be presented in

331 tables. Key variables included soil-HM concentration ( $\mathrm{m} \mathrm{kg}^{-1}$ dry soil), plant $\mathrm{HM}$ concentration

332 ( $\mathrm{mg} \mathrm{kg}^{-1}$ dry mass) and/or content (mg plant $\left.{ }^{-1}\right)$ for shoots and/or roots, and plant dry mass (g) for 333 shoots and/or roots.

\section{$334 \quad$ 2.2. Metrics}

Total plant $\mathrm{HM}$ content $\left(\mathrm{HM}_{\text {plant }}\right)$ and plant $\mathrm{HM}$ concentration ([ $\left.\mathrm{HM}_{\text {plant }}\right]$ ) were used to

336 measure the actual plant HM uptake. The specific extraction yield percentage (SEY\%) and

337 bioconcentration factor (BCF) were used to measure the plant $\mathrm{HM}$ uptake relative to the $\mathrm{HM}$ in

338 soil. The $\mathrm{SEY}_{\%}$, representing the percent ratio of plant $\mathrm{HM}$ content to soil-HM concentration

$339\left(\left[\mathrm{HM}_{\text {soil }}\right]\right)$ (adapted from Audet \& Charest 2006), is defined as:

$$
S E Y_{\%}=\frac{H M_{\text {plant }}}{\left[H M_{\text {soil }}\right]}
$$


343 The BCF, representing the ratio of plant HM concentration to soil-HM concentration (Dowdy

344 and McKone 1997), is defined as:

$$
B C F=\frac{\left[H M_{\text {plant }}\right]}{\left[H M_{\text {soil }}\right]}
$$

346 Typically, the BCF is an indication of the magnification of contaminants from a lower to a 347 higher trophic level (Newman and Unger 2003). For plants, the BCF has been used as a measure 348 of HM accumulation efficiency, whereby values greater than 1 are an indication of potential HM 349 phytohyperaccumulator species (Zhang et al. 2002). The tolerance index (TI), representing the 350 ratio of biomass for plants grown in HM-soil to plants grown in non-HM control-soil for roots 351 and shoots separately (Wilkins 1957, 1978), is defined as:

$$
\boldsymbol{T I}=\frac{\text { biomass }_{H M}}{\text { biomass }_{\text {control }}}
$$

353 TI values lower than 1 indicate a net decrease in biomass and suggest that the plants are stressed, 354 whereas TI values equal to 1 indicate no difference relative to non-HM control treatments. Also, 355 TI values greater than 1 indicate a net increase in biomass and suggest that plants express a 356 growth dilution effect.

\subsection{Statistical analyses}

The Pearson product-moment correlation test (Zar 1999) was used to calculate the significance and strength of the following correlations: between the total HM tissue content, HM tissue concentration, $\mathrm{SEY} \%, \mathrm{BCF}$, or TI and soil-HM concentration, and between the TI and total

362 for variance attributable to differences in HM type, plant species, reference source, plant tissue 363 type (either shoot or root), and study type (either field or laboratory study). This was done by 364 adding these terms to the statistical model and solving for the coefficient of determination $\left(r^{2}\right)$ 365 (data not shown). The correlations were also calculated for each $\mathrm{HM}$ (e.g. $\mathrm{Zn}, \mathrm{Cd}, \mathrm{Pb}, \mathrm{Cu}, \mathrm{Ni}$, 
$366 \mathrm{Cr}, \mathrm{Co}, \mathrm{Mn}$, and $\mathrm{Fe}$ ) for all comparison variables representing the HM-specific correlation

367 coefficients, with the exception of the comparisons involving the TI that did not show any

368 significant HM-specific correlations (data not shown). The empty coefficient fields for the

369 individual HM (Tables 2 and 3) indicate that the correlation model cannot be fitted with any

370 variables since the data analyzed were taken from either one plant species, reference source,

371 plant tissue type, or study type only. The Fisher correlation comparison test was used to

372 compare coefficient values (Zar 1999). We applied logarithmic transformations to each of the

373 variables in order to detect any linear relationship between the variables, and to meet normal

374 distribution and homoscedasticity assumptions during analysis. We analyzed the residual rather

375 than the raw values of $\mathrm{SEY}_{\%}$ and $\mathrm{BCF}$ in order to detect any trend underlying the negative

376 relationship between $\left[\mathrm{HM}_{\text {soil }}\right]$ with $\mathrm{SEY}_{\%}$ or BCF. All of the p-values were determined using S-

$377 \quad$ Plus@ 7.0 (Insightful 2005).

378

$379 \quad$ 3. RESULTS

380 The total plant HM content (Fig.1a) and plant HM concentration (Fig.1b) were plotted

381 versus the soil-HM concentration; their correlation coefficients with $\left[\mathrm{HM}_{\text {soil }}\right]$ were 0.53 and 0.50 ,

382 respectively (Table 1). The correlation coefficients for the total plant HM content and

383 concentration were significantly increased once fitted for heavy metal type (0.65 and 0.61$)$, and

384 the strongest values were observed after fitting the reference source $(0.75$ and 0.73$)$, or species

385 type (0.76 and 0.82$)$. The fitted coefficients for the study type showed no significant differences

386 from the unfitted values. The HM-specific correlation coefficients for the total plant HM content

387 and concentration were all significant and positive, with the exception of $\mathrm{Cr}$ and $\mathrm{Mn}$ showing no

388 significant correlations (Table 2). Once fitted for reference source or species type, the strength

389 of correlation significantly increased in all cases. Likewise, the HM-specific correlation 
390 coefficients for total plant HM content and soil-HM concentration were all significant and

391 positive, with the exception of $\mathrm{Cr}$ and $\mathrm{Fe}$ showing no significant correlations (Table 2). Again,

392 the coefficients significantly increased in all cases once fitted for reference source and species

393 type.

394 The residual values for the SEY\% (Fig.2a) and BCF (Fig.2b) were plotted against the soil-

395 HM concentration; their correlation coefficients were -0.54 and -0.52 , respectively (Table 3 ).

396 The correlation coefficients for the SEY $\%$ and BCF were significantly decreased once fitted for

397 the HM type (-0.64 and -0.61$)$, and the strongest once fitted for the reference source $(-0.75$ and -

$398 \quad 0.80)$ and the species type (-0.74 and -0.81). The fitted coefficients for the study type showed

399 no significant differences from the unfitted values. The HM-specific correlation coefficients for

400 residual $\mathrm{SEY}_{\%}$ and residual BCF were mostly all significant and negative (Table 3). However,

401 the $\mathrm{SEY}_{\%}$ coefficients of $\mathrm{Pb}, \mathrm{Ni}, \mathrm{Cr}$, and $\mathrm{Mn}$ indicated non-significant correlations, while $\mathrm{Co}$

402 showed a significant and positive correlation with soil-HM concentration. Furthermore, the BCF

403 coefficients of $\mathrm{Cr}$ and $\mathrm{Fe}$ showed non-significant correlations, while $\mathrm{Ni}, \mathrm{Co}$, and Mn showed

404 significant and positive correlations with soil-HM concentration. For the SEY\% and BCF

405 correlations, the coefficients for nearly all the HM were the strongest once fitted for the reference

$406 \quad$ source and species type.

407 The TI values plotted against the soil-HM concentration (Fig.3a), total plant HM content

408 (Fig.3b), and plant HM concentration (Fig.3c) showed significant and negative correlations with

409 soil-HM concentration (-0.21) or plant HM concentration (-0.19), whereas the soil-HM content

410 showed no significant correlation (Table 4). All of these coefficients were significant and

411 strongest once fitted for species type $(-0.49,-0.44$, and -0.49$)$ and reference source $(-0.55,-0.49$,

412 and -0.54). Only the correlation between plant HM content and TI showed non-significant

413 coefficients when fitted for HM type, plant tissue type, or study type. 


\section{$415 \quad$ 4. DISCUSSION}

We observed that both plant HM content and concentration, which are indicators of

417 actual plant HM uptake, strongly and significantly increase as soil-HM concentration increases;

418 this trend being found for each individual HM studied. This is remarkable considering that some

419 plants tolerate high tissue HM content or concentration, with levels as high as $325 \mathrm{mg}^{\mathrm{Ni}} \mathrm{DM}^{-1}$

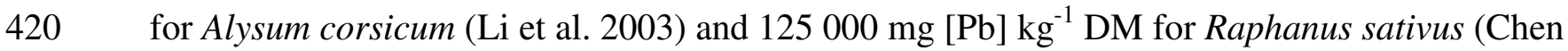

421 et al. 2003a), while soil-HM concentration increased by approximately three to five orders of

422 magnitude. In this regard, the predictive model for actual plant HM uptake from our meta-

423 analytical results suggests that plants are able to accumulate heavy metals at higher soil-HM

424 concentrations, and then an even greater potential for phytoremediation purposes than indicated

425 in published reports so far. This is in agreement with the criterion that an effective HM

426 phytoextraction requires that plants be increasingly tolerant to high plant-HM and soil-HM

427 concentrations (Chaney et al. 1997; Meagher 2000; Pilon-Smits 2005; Salt et al. 1995, 1998).

428 On the other hand, both $\mathrm{SEY}_{\%}$ and $\mathrm{BCF}$, indicators of relative plant HM uptake, were shown to

429 strongly and significantly decrease as soil-HM concentration increases; this trend being found for

430 each HM studied, with few exceptions. Hence, HM phytoextraction was declining relative to

431 increasing soil-HM concentration, even though the actual HM uptake was linearly increasing.

432 This response of decreased relative uptake is likely linked to the increased cost associated with

433 tolerance to high plant HM levels, for example the cost of phytochelatin production or HM

434 sequestration (Cobbett 2000; Maier et al. 2003; Wang et al. 2005). Furthermore, the decrease in

435 relative plant HM uptake could also be the result of direct and/or indirect challenges such as HM

$436 \quad$ toxicity causing plant poisoning, soil pH changes, and mineral imbalances (Foy et al. 1978;

437 Marschner 1986), all of which similarly affecting the soil microbiota and their interactions with 
plants (Giller et al. 1998; Hayman and Tavares 1985; Leyval et al. 1997; McGrath et al. 1995).

439 From our results, the predictive model for relative plant HM uptake suggests that HM

440 phytoextraction becomes less effective as soil-HM concentration increases when the metabolic

441 costs of HM uptake and sequestration are taken into consideration. This, therefore, challenges

442 the aforementioned criteria for effective phytoextraction.

443 As for the individual HM studied, all share, at varying strengths, the general trend of

444 positive correlation between plant HM content or concentration and soil-HM concentration,

445 despite some non-significant correlations (e.g. Cr, Mn, and Fe with df < 28). In this case, non-

446 significant correlations may be attributed to the small sample size or the narrow soil-HM

447 concentrations less than one order of magnitude. For these reasons, the actual uptake correlation

448 values for $\mathrm{Cr}, \mathrm{Mn}$, and Fe cannot be considered representative of any significant biological

449 trends until more data are available. As for the correlations between residual values of SEY\% or

450 BCF with soil-HM concentration, all of the HM studied show negative correlations, with the

451 exception of $\mathrm{Ni}, \mathrm{Co}$, and $\mathrm{Mn}$. The non-significant correlations observed can be attributed to the

452 effects of sample size or soil concentration range as previously stated, particularly for Co and

453 Mn. However, any positive $\mathrm{SEY}_{\%}$ or BCF correlations imply that plants show higher relative

454 uptake of $\mathrm{Ni}, \mathrm{Co}$, and $\mathrm{Mn}$ under increasing soil-HM concentrations, thus indicating their greater

455 phytoremediation potential compared to the other HM studied. In this regard, the relative plant

456 HM uptake may be affected by edaphic conditions, particularly soil-HM bioavailability (Walker

457 et al. 2003). For example, a plant uptake likely increase as soil-pH becomes acidic, relating to

458 increased HM bioavailability when colloidal sorption decreases (Apak 2002). Hence, plant HM

459 levels may be higher when grown in more acidic soil conditions, then explaining differences in

$460 \quad$ HM-specific uptake. 
From our meta-analytical results, the TI values, which represent relative plant growth,

463 decreased as the plant or soil-HM concentrations increased while there was no significant

464 correlation between TI and total plant HM content. Accordingly, the potential for

465 phytoextraction is likely affected by the rate of HM uptake rather than the level of HM tolerance,

466 meaning that high biomass species may take up greater total HM content than low biomass

467 species while possibly tolerating equal plant HM concentration. Nevertheless, we have provided 468 evidence that plants subjected to soil-HM conditions are in the zone of nutrient toxicity and that 469 any further HM uptake would eventually result in plant death; this being in agreement with the 470 generalized relationship between plant growth and nutrient concentration (Epstein 1972). This is 471 an indication that plants are becoming increasingly stressed, with their overall health declining 472 under such soil-HM conditions. In our study, there is some incidence of increased plant growth 473 under HM relative to non-HM conditions, yet this was not observed in conjunction with any 474 decrease in plant HM concentration. Therefore, it may be interpreted that plants do not use any 475 mechanism of growth dilution effect in tolerating soil-HM stress, a process in which the 476 concentration of any compound decreases subsequent to its distribution in the growing biomass 477 (Newman and Unger 2003). Instead, our findings strongly suggest a compromise with regard to 478 plant resource allocation, this affecting plant capacity for HM uptake, tolerance, and growth 479 under soil-HM conditions. In view of these metabolic costs, high biomass plants (e.g. Zea mays 480 and Nicotiana sp.) have seldom been shown to take up higher HM concentration than some low 481 biomass plants (e.g. Alysum corsicum and Raphanus sativus). Therefore, HM phytoextraction 482 under increasing soil-HM concentrations would decline, and be limited to only better adapted or 483 hyperaccumulator species (Xue et al. 2004; Yanai et al. 2006).

As for the fitted correlation coefficients, these values can also be interpreted as measures 485 of variance between the different plant species chosen or the different experimental parameters 
486 (e.g. HM, plant tissue, or study type), as compared with the unfitted values. Notably, the

487 correlation values were significantly strongest once fitted for reference and plant species type;

488 therefore, the highest proportion of variance is attributable to the different methods or treatments

489 used in each study as well as the different plant species studied. It has been reported that

$490 \quad$ chelating agents enhance plant HM uptake (Blaylock et al. 1997; Chen et al. 2003b; Cui et al.

491 2004; Jiang and Yang 2004). It has also been shown that hyperaccumulators often tolerate and

492 take up higher HM levels compared to non-hyperaccumulator species (Delorme et al. 2001;

493 Marchiol et al. 2004; Shen et al. 2002). Moreover, the correlation values fitted for plant tissue or

494 study type were mostly not different from the unfitted values, and therefore account for only a

495 small proportion of the variance in our study. This has occurred even though plant HM uptake

496 levels were not necessarily the same in both shoots and roots for different plant species or HM

497 type (Chaney et al. 1997), and despite the fact that these plant HM levels differed between

498 laboratory and field conditions (Huang and Cunningham 1996).

499

500 5. CONCLUSION

$501 \quad$ Our meta-analytical study has quantified key relationships involving the physiology of

502 plants and the HM phytoextraction process. From these results, we should reject the assertion

503 that HM phytoextraction is an effective means of soil remediation under increasing soil-HM

504 levels. In this regard, it would be important to better understand the metabolic compromises in

505 plants between investing in HM tolerance and growth in a bioremediation perspective.

506 ACKNOWLEDGMENTS

507 The authors wish to thank the Editor-in-Chief and the two anonymous referees for this

508 publication. This research was funded by a grant from the Natural Sciences and Engineering

509 Research Council of Canada (NSERC) to Ch Ch. 


\section{REFERENCES}

Apak, R., 2002. Adsorption of heavy metal ions on soil surfaces and similar substances, in: Hubbard, A. (Ed.), Encyclopedia of Surface and Colloid Science. Dekker, New York, pp Audet, P., Charest, C., 2006. Effects of AM colonization on "wild tobacco" plants grown in zinccontaminated soil. Mycorrhiza 16, 277-283.

Blaylock, M.J., Salt, D.E., Dushenkov, S., Zakharov, O., Gussman, C., Kapulnik, Y., Ensley, B.D., Raskin, I., 1997. Enhanced accumulation of $\mathrm{Pb}$ in indian mustard by soil applied chelating agents. Environmental Science and Technology 31, 860-865.

Chaney, R.L., Malik, M., Li, Y.M., Brown, S.L., Brewer, E.P., Angle, J.S., Baker, A.J.M., 1997. Phytoremediation of soil metals. Current Opinions in Biotechnology 8, 279-284.

Chen, B.D., Li, X.L., Tao, H.Q., Christie, P., Wong, M.H., 2003a. The role of arbuscular mycorrhiza in zinc uptake by red clover growing in a calcareous soil spiked with various quantities of zinc. Chemosphere 50, 839-846.

Chen, Y.X., Lin, Q., Luo, Y.M., He, Y.F., Zhen, S.J., Yu, Y.L., Tian, G.M., Wong, M. 2003 b. The role of citric acid on the phytoremediation of heavy metal contaminated soil. Chemosphere 50, 807-811.

Cobbett, C.S., 2000. Phytochelatins and their roles in heavy metal detoxification. Plant Physiology 123, 825-832.

Cui, Y., Wang, Q., Dong, Y., Li, H., Christie, P., 2004. Enhanced uptake of soil Pb and Zn by Indian mustard and winter wheat following combined soil application of elemental sulphur and EDTA. Plant and Soil 261, 181-188.

Cunningham, S.D., Berti, W.R., Huang, J.W., 1995. Phytoremediation of contaminated soils. Trends in Biotechnology 13, 393-397. 
Delorme, T.A., Gagliardi, J.V., Angle, J.S., Chaney, R.L., 2001. Influence of the zinc hyperaccumulator Thlaspi caerulescens J. \& C. Presl. and the nonmetal accumulator Trifolium pratense L. on soil microbial populations. Canadian Journal of Microbiology 47, 773-776.

Dowdy, D.L., McKone, T.E., 1997. Predicting plant uptake of organic chemicals from soil or air using octanol/water and octanol/air partitioning ratios and a molecular connectivity index. Environmental Toxicology and Chemistry 16, 2448-2456.

Epstein, E., 1972. Mineral nutrition of plants: principles and perspectives, Wiley, New York.

Foy, C.D., Chaney, R.L., White, M.C., 1978. The physiology of metal toxicity in plants. Annual Review of Plant Physiology 29, 511-566.

Giller, K.E., Witter, E., McGrath, S.P., 1998. Toxicity of heavy metals to microorganisms and microbial processes in agricultural soils: a review. Soil Biology and Biochemistry 30, 1389-1414.

Hayman, D.S., Tavares, M., 1985. Plant growth responses to vesicular-arbuscular mycorrhizae. $\mathrm{XV}$. Influence of soil $\mathrm{pH}$ on the symbiotic efficiency of different endophytes. New Phytologist 100, 367-377.

Hedges, L.V., Olkin, I., 1985. Statistical Methods for Meta-Analysis, Academic Press, Orlando. Huang, J.W., Chen, J., Berti, W.R., Cunningham, S.D., 1997. Phytoremediation of leadcontaminated soils: role of synthetic chelates in lead phytoextraction. Environmental Science and Technology 31, 800-805.

Insightful Corp., 2005. S-Plus® 7.0 for Windows. Seattle.

Jiang, L.Y., Yang, X.E., 2004. Chelators effect on soil Cu extractability and uptake by Elsholtzia splendens. Journal of Zhejiang University Science 5, 450-456. 
Leyval, C., Turnau, K., Haselwandter, K., 1997. Effect of heavy metal pollution on mycorrhizal colonization and function: physiological, ecological, and applied aspects. Mycorrhiza 7, 139-153.

Lipsey, M.W., Wilson, D.B., 2001. Practical Meta-Analysis, SAGE publications, Thousand Oaks.

Li, Y.M., Chaney, R.L., Brewer, E.P., Angle, J.S., Nelkin, J., 2003. Phytoextration of nickel and cobalt by hyperaccumulator Alyssum species grown on nickel-contaminated soils. Environmental Science and Technology 37, 1463-1468.

Maier, E.A., Matthews, R.D., MacDowell, J.A., Walden, R.R., Ahner, B.A., 2003. Environmental cadmium levels increase phytochelatin and glutathion in lettuce grown in a chelator-buffered nutrient solution. Journal of Environmental Quality 32, 1356-1364.

Marchiol, L., Assolari, S., Sacco, P., Zerbi, G., 2004. Phytoextraction of heavy metals by canola (Brassica napus) and radish (Raphanus sativus) grown on multicontaminated soil. Environmental Pollution 132, 21-27.

Marschner, H., 1995. Mineral nutrition of higher plants, second ed. Academic Press, Toronto. McGrath, S.P., Chaudri, A.M., Giller, K.E., 1995. Long-term effects of metals in sewage sludge on soils, microorganisms and plants. Journal of Industrial Microbiology 14, 94-104.

Meagher, R.B., 2000. Phytoremediation of toxic elemental and organic pollutants. Current Opinions in Plant Biology 3, 153-162.

Newman, M.C., Unger, M.A., 2003. Fundamentals of ecotoxicology, second ed., Lewis, Boca Raton.

Pilon-Smits, E., 2005. Phytoremediation. Annual Review of Plant Biology 56, 15-39.

Salt, D.E., Blaylock, M., Kumar, N.P.B.A., Dushenkov, V., Ensley, B.D., Chet, I., Raskin, I., 1995. Phytoremediation: a novel strategy for the removal of toxic metals from the 
Environment using plants. Biotechnology 13, 468-474.

583 Salt, D.E., Smith, R.D., Raskin, I., 1998. Phytoremediation. Annual Review of Plant Physiology and Plant Molecular Biology 49, 643-648.

Shen, Z.G., Li, Z.D., Wang, C.C., Chen, H.M., Chua, H., 2002. Lead phytoextraction from contaminated soil with high-biomass plant species. Journal of Environmental Quality 31, 1893-1900.

Walker, D.J., Clemente, R., Roig, A., Bernal, M.P., 2003. The effects of soil amendments on heavy metal bioavailability in two contaminated Mediterranean soils. Environmental Pollution 122, 303-312. 269, 225-232. 37-38.

Wang, F., Lin, X., Yin, R., 2005. Heavy metal uptake by arbuscular mycorrhizas of Elsholtzia splendens and the potential for phytoremediation of contaminated soil. Plant and Soil

Wilkins, D.A., 1957. A technique for the measurement of lead tolerance in plants. Nature 180,

Wilkins, D.A., 1978. The measurement of tolerance to edaphic factors by means of root growth. New Phytologist 80, 623-633.

Xue, S.G., Chen, Y.X., Reeves, R.D., Baker, A.J.M., Lin, Q., Fernando, D.R., 2004. Manganese uptake and accumulation by the hyperaccumulator plant Phytolacca acinosa Roxb. (Phytolaccaceae). Environmental Pollution 131, 393-399. 
606 Figure 1. Plant HM content $\left(\mathrm{mg} \mathrm{DM}^{-1}\right)$ (a) and concentration $\left(\mathrm{mg} \mathrm{kg}^{-1} \mathrm{DM}\right)(\mathrm{b})$ in relation with 607 soil-HM concentration ( $\mathrm{mg} \mathrm{kg}^{-1}$ dry soil).

608

609 Figure 2. Residual SEY $\%$ (a) and residual BCF (b) in relation with soil-HM concentration

610 (mg kg-1 dry soil).

611

612 Figure 3. TI in relation with soil-HM concentration ( $\mathrm{mg} \mathrm{kg}^{-1}$ dry soil) (a), plant $\mathrm{HM}$ content (mg $\left.613 \mathrm{DM}^{-1}\right)(\mathrm{b})$, and plant $\mathrm{HM}$ concentration $\left(\mathrm{mg} \mathrm{kg}^{-1} \mathrm{DM}\right)(\mathrm{c})$. The reference line indicates 614 the TI value of 1. 

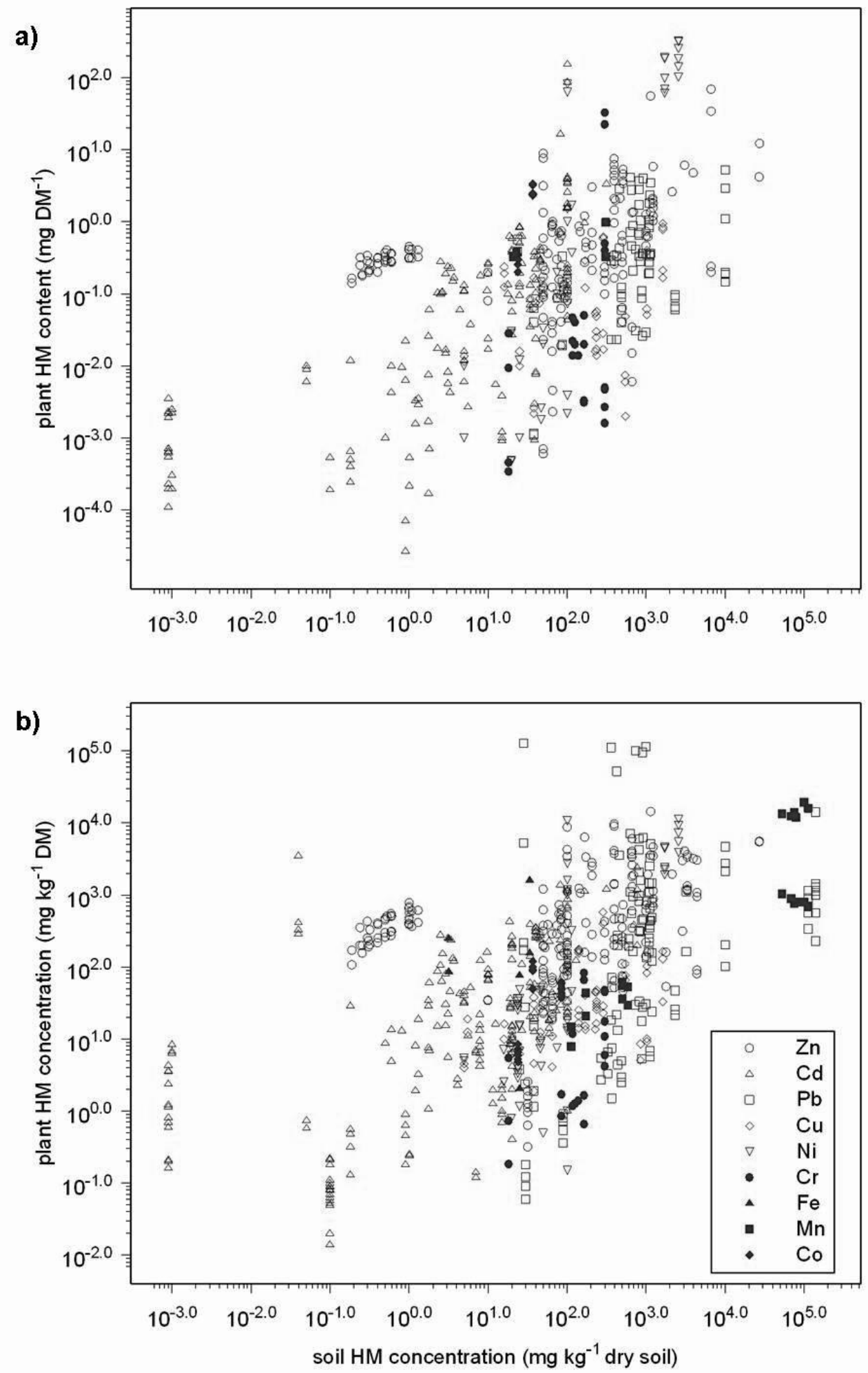

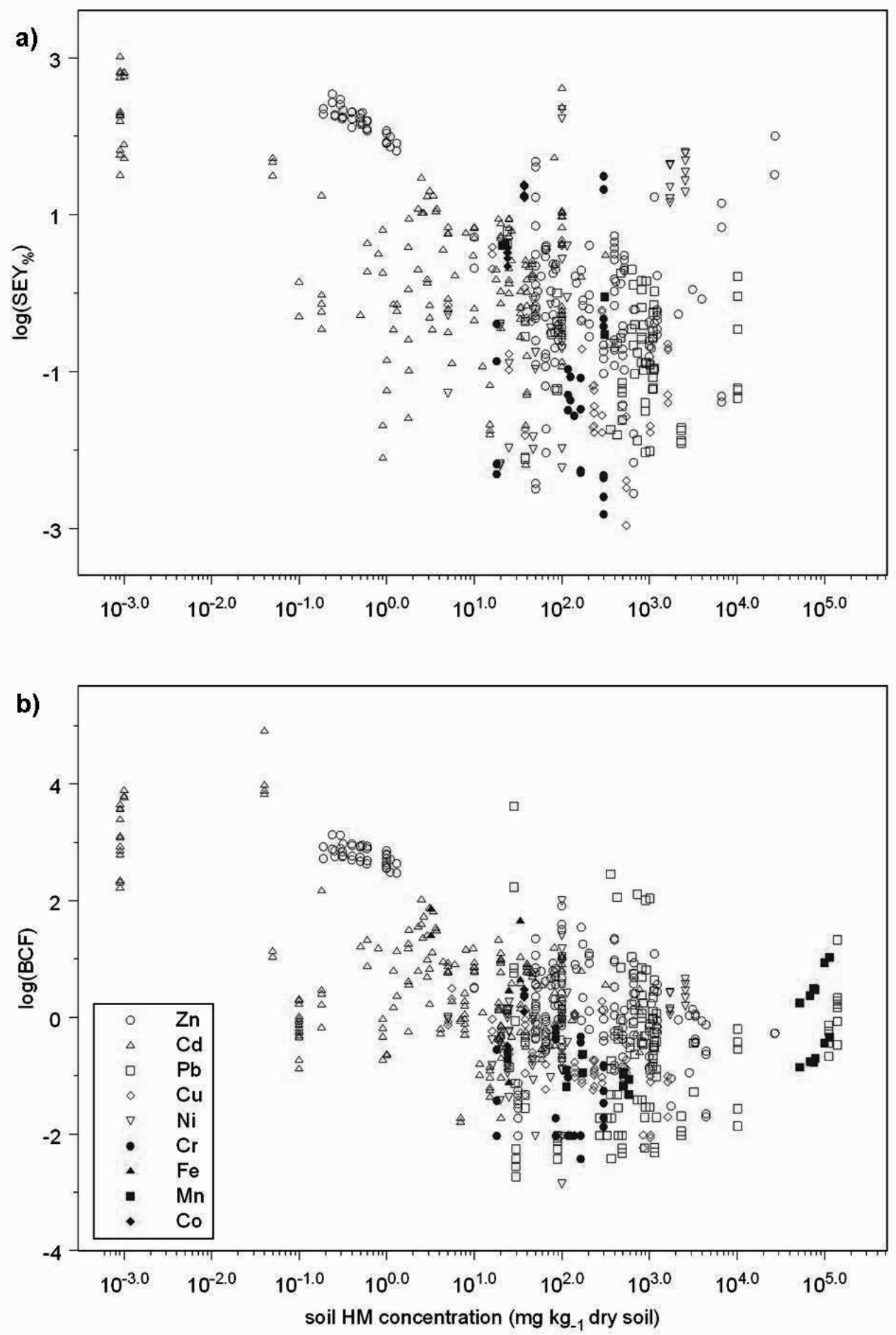

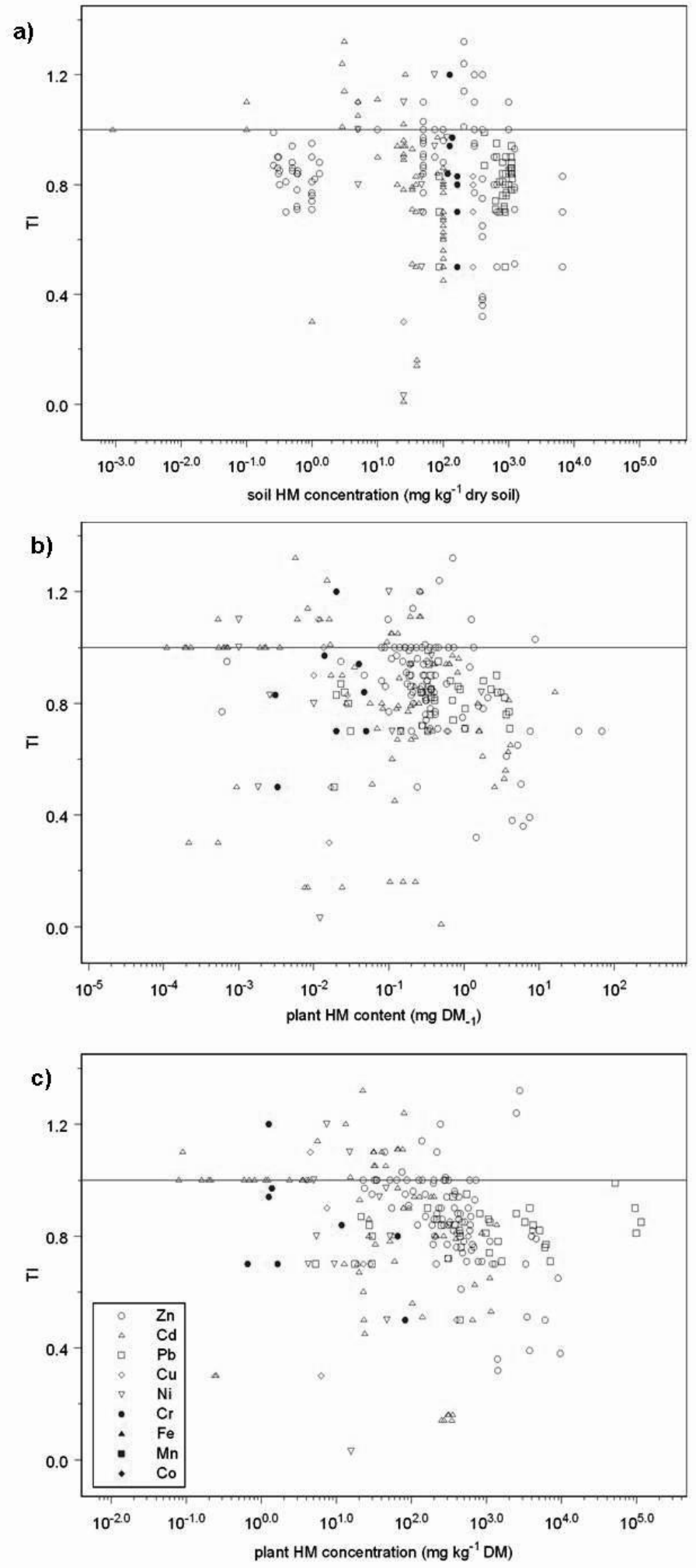
618 Table 1. Correlation coefficients (r) for the plant $\mathrm{HM}$ content $\left(\mathrm{HM}_{\text {plant }}\right)$, plant $\mathrm{HM}$ concentration ([HM $\left.\mathrm{Hlant}_{\mathrm{N}}\right)$, residual 619 specific extraction yield percentage ( $\mathrm{SEY}_{\%}$ ), and residual bioconcentration factor (BCF) in relation with the soil-HM 620 concentration $\left(\left[\mathrm{HM}_{\text {soil }}\right]\right)$. The $\mathrm{r}$ values for raw and fitted coefficients (heavy metal type, $\mathrm{r}_{\mathrm{HM}} ;$ reference, $\mathrm{r}_{\mathrm{r}} ;$ species, $\mathrm{r}_{\mathrm{s}}$; 621 plant tissue type, $\mathrm{r}_{\mathrm{t}}$; study type, $\mathrm{r}_{\mathrm{st}}$ ) and degrees of freedom (df) are shown.

\begin{tabular}{|c|c|c|c|c|c|c|c|}
\hline Variables & df & $\mathrm{r}$ & $\mathrm{r}_{\mathrm{HM}}$ & $\mathrm{r}_{\mathrm{sp}}$ & $r_{r}$ & $r_{t}$ & $r_{s t}$ \\
\hline $\mathrm{HM}_{\text {plant }}$ & 508 & $0.53^{\mathrm{c}}$ & $0.65^{\mathrm{b}}$ & $0.75^{\mathrm{a}}$ & $0.76^{\mathrm{a}}$ & $0.56^{\mathrm{bc}}$ & $0.55^{\mathrm{c}}$ \\
\hline$\left[\mathrm{HM}_{\text {plant }}\right]$ & 761 & $0.50^{\mathrm{d}}$ & $0.61^{\mathrm{c}}$ & $0.73^{\mathrm{b}}$ & $0.82^{\mathrm{a}}$ & $0.59^{\mathrm{c}}$ & $0.51^{\mathrm{d}}$ \\
\hline $\mathrm{SEY}_{\%}$ & 508 & $-0.54^{\mathrm{c}}$ & $-0.64^{b}$ & $-0.75^{\mathrm{a}}$ & $-0.74^{\mathrm{a}}$ & $-0.55^{\mathrm{c}}$ & $-0.54^{\mathrm{c}}$ \\
\hline $\mathrm{BCF}$ & 761 & $-0.52^{c}$ & $-0.61^{b}$ & $-0.80^{\mathrm{a}}$ & $-0.81^{\mathrm{a}}$ & $-0.52^{c}$ & $-0.59^{c}$ \\
\hline
\end{tabular}

622 All p-values $<0.01$. Different letters within each row indicate significant differences between correlation

623 coefficients according to Fisher's comparison test at $\mathrm{p}<0.05$. 
Table 2. HM-specific correlation coefficients (r) for the plant $\mathrm{HM}$ content $\left(\mathrm{HM}_{\mathrm{plant}}\right)$ and concentration ([HM $\left.\mathrm{Hlant}_{\mathrm{p}}\right)$ in relation with the soil-HM concentration $\left(\left[\mathrm{HM}_{\text {soil }}\right]\right)$. The $\mathrm{r}$ values for raw and fitted coefficients (reference, $\mathrm{r}_{\mathrm{r}}$; species, $\mathrm{r}_{\mathrm{s}}$; plant tissue type, $\mathrm{r}_{\mathrm{t}}$; study type, $\mathrm{r}_{\mathrm{st}}$ ) and degrees of freedom (df) are shown.

\begin{tabular}{|c|c|c|c|c|c|c|c|c|c|c|c|c|}
\hline \multirow[t]{2}{*}{$\mathrm{HM}$} & \multicolumn{6}{|c|}{$\mathrm{HM}_{\text {plant }}$} & \multicolumn{6}{|c|}{$\left[\mathrm{HM}_{\text {plant }}\right]$} \\
\hline & df & $\mathrm{r}$ & $r_{r}$ & $\mathrm{r}_{\mathrm{sp}}$ & $r_{t}$ & $\mathrm{r}_{\mathrm{st}}$ & $\mathrm{df}$ & $\mathrm{r}$ & $r_{r}$ & $\mathrm{r}_{\mathrm{sp}}$ & $r_{t}$ & $\mathrm{r}_{\mathrm{st}}$ \\
\hline $\mathrm{Zn}$ & 186 & $0.29^{c}$ & $0.73^{\mathrm{a}}$ & $0.59^{\mathrm{b}}$ & $0.39^{c}$ & $0.33^{\mathrm{c}}$ & 202 & $0.24^{\mathrm{c}}$ & $0.90^{\mathrm{a}}$ & $0.84^{\mathrm{a}}$ & $0.25^{\mathrm{c}}$ & $0.71^{\mathrm{b}}$ \\
\hline $\mathrm{Cd}$ & 156 & $0.71^{\mathrm{b}}$ & $0.85^{\mathrm{a}}$ & $0.85^{\mathrm{a}}$ & $0.71^{\mathrm{b}}$ & $0.75^{\mathrm{b}}$ & 211 & $0.56^{\mathrm{b}}$ & $0.90^{\mathrm{a}}$ & $0.86^{\mathrm{a}}$ & $0.57^{\mathrm{b}}$ & $0.67^{\mathrm{b}}$ \\
\hline $\mathrm{Pb}$ & 80 & $0.40^{\mathrm{b}}$ & $0.44^{\mathrm{b}}$ & $0.76^{\mathrm{a}}$ & $0.55^{\mathrm{b}}$ & $0.56^{\mathrm{b}}$ & 142 & $0.05^{\mathrm{d}}$ & $0.85^{\mathrm{a}}$ & $0.77^{\mathrm{b}}$ & $0.52^{\mathrm{c}}$ & $0.44^{\mathrm{c}}$ \\
\hline $\mathrm{Cu}$ & 44 & $0.34^{\mathrm{b}}$ & $0.57^{\mathrm{b}}$ & $0.80^{\mathrm{a}}$ & $0.60^{\mathrm{ab}}$ & $0.48^{\mathrm{b}}$ & 64 & $0.39^{\mathrm{b}}$ & $0.73^{\mathrm{a}}$ & $0.61^{\mathrm{b}}$ & $0.55^{\mathrm{ab}}$ & $0.43^{\mathrm{b}}$ \\
\hline $\mathrm{Ni}$ & 36 & $0.89^{\mathrm{a}}$ & $0.90^{\mathrm{a}}$ & $0.89^{\mathrm{a}}$ & $0.89^{\mathrm{a}}$ & $0.79^{\mathrm{a}}$ & 64 & $0.78^{\mathrm{b}}$ & $0.81^{\mathrm{b}}$ & $0.89^{\mathrm{ab}}$ & $0.79^{\mathrm{b}}$ & $0.78^{\mathrm{b}}$ \\
\hline $\mathrm{Cr}$ & 20 & $0.43^{\text {ns }}$ & $0.48^{\mathrm{ns}}$ & $0.46^{\mathrm{ns}}$ & $0.52^{\mathrm{ns}}$ & $0.46^{\mathrm{ns}}$ & 28 & $0.35^{\mathrm{ns}}$ & $0.51^{\mathrm{a}}$ & $0.46^{\mathrm{ns}}$ & $0.76^{\mathrm{a}}$ & $0.46^{\mathrm{ns}}$ \\
\hline Co & 10 & 0.99 & & & & & 10 & $0.99^{\mathrm{a}}$ & & & & \\
\hline Mn & 2 & $0.52^{\mathrm{ns}}$ & $0.99^{\mathrm{ns}}$ & & $0.53^{\mathrm{ns}}$ & & 20 & $0.91^{\mathrm{a}}$ & $0.89^{\mathrm{a}}$ & $0.89^{\mathrm{a}}$ & $0.91^{\mathrm{a}}$ & $0.90^{\mathrm{a}}$ \\
\hline $\mathrm{Fe}$ & & & & & & & 4 & $-0.06^{\mathrm{ns}}$ & $0.77^{\mathrm{ns}}$ & $0.77^{\mathrm{ns}}$ & $-0.06^{\mathrm{ns}}$ & \\
\hline
\end{tabular}

All p-values $<0.01$ except those indicated with ns, non-significant. Different letters within each row indicate significant differences between correlation

coefficients according to Fisher's comparison test at $\mathrm{p}<0.05$. Empty coefficient fields indicate that the correlation model cannot be fitted with variables since the data analyzed were taken from either one plant species, reference source, plant tissue type, or study type only. 
Table 3. HM-specific correlation coefficients for the residual specific extraction yield percentage ( $\mathrm{SEY}_{\%}$ ) and residual bioconcentration factor (BCF) in relation with the soil-HM concentration $\left(\left[\mathrm{HM}_{\text {soil }}\right]\right)$. The $\mathrm{r}$ values for raw and fitted coefficients (reference, $\mathrm{r}_{\mathrm{r}}$; species, $\mathrm{r}_{\mathrm{s}} ;$ plant tissue type, $\mathrm{r}_{\mathrm{t}}$; study type, $\left.\mathrm{r}_{\mathrm{st}}\right)$ and degrees of freedom (df) are shown.

\begin{tabular}{|c|c|c|c|c|c|c|c|c|c|c|c|c|}
\hline \multirow[t]{2}{*}{ HM } & \multicolumn{6}{|c|}{$\mathrm{SEY}_{\%}$} & \multicolumn{6}{|c|}{$\mathrm{BCF}$} \\
\hline & $\mathrm{df}$ & $\mathrm{r}$ & $\mathrm{r}_{\mathrm{r}}$ & $\mathrm{r}_{\mathrm{sp}}$ & $r_{t}$ & $\mathrm{r}_{\mathrm{st}}$ & $\mathrm{df}$ & $\mathrm{r}$ & $\mathrm{r}_{\mathrm{r}}$ & $\mathrm{r}_{\mathrm{sp}}$ & $r_{t}$ & $\mathrm{r}_{\mathrm{st}}$ \\
\hline $\mathrm{Zn}$ & 186 & $-0.73^{c}$ & $-0.89^{\mathrm{a}}$ & $-0.82^{b}$ & $-0.75^{b c}$ & $-0.73^{c}$ & 202 & $-0.73^{c}$ & $-0.96^{\mathrm{a}}$ & $-0.92^{\mathrm{a}}$ & $-0.73^{c}$ & $-0.83^{b}$ \\
\hline $\mathrm{Cd}$ & 156 & $-0.55^{\mathrm{b}}$ & $-0.79^{\mathrm{a}}$ & $-0.79^{a}$ & $-0.56^{\mathrm{b}}$ & $-0.62^{b}$ & 211 & $-0.63^{b}$ & $-0.91^{\mathrm{a}}$ & $-0.88^{\mathrm{a}}$ & $-0.64^{b}$ & $-0.72^{b}$ \\
\hline $\mathrm{Pb}$ & 80 & $-0.18^{\mathrm{ns}}$ & $-0.61^{\mathrm{ab}}$ & $-0.67^{\mathrm{a}}$ & $-0.38^{b}$ & $-0.56^{\mathrm{ab}}$ & 142 & $-0.21^{\mathrm{c}}$ & $-0.79^{\mathrm{a}}$ & $-0.68^{b}$ & $-0.23^{c}$ & $-0.23^{c}$ \\
\hline $\mathrm{Cu}$ & 44 & $-0.55^{\mathrm{b}}$ & $-0.81^{\mathrm{ab}}$ & $-0.84^{\mathrm{a}}$ & $-0.69^{\mathrm{ab}}$ & $-0.61^{b}$ & 64 & $-0.68^{b}$ & $-0.84^{\mathrm{a}}$ & $-0.77^{b}$ & $-0.74^{\mathrm{ab}}$ & $-0.69^{b}$ \\
\hline $\mathrm{Ni}$ & 36 & $0.74^{\mathrm{ns}}$ & $0.77^{\mathrm{a}}$ & $0.76^{\mathrm{a}}$ & $0.75^{\mathrm{a}}$ & $0.75^{\mathrm{a}}$ & 64 & $0.34^{\mathrm{b}}$ & $0.48^{b}$ & $0.73^{\mathrm{a}}$ & $0.39^{\mathrm{b}}$ & $0.36^{\mathrm{b}}$ \\
\hline $\mathrm{Cr}$ & 20 & $0.11^{\mathrm{ns}}$ & $-0.79^{\mathrm{a}}$ & $-0.21^{\mathrm{ns}}$ & $-0.33^{b}$ & $-0.22^{\mathrm{ns}}$ & 28 & $-0.17^{\mathrm{ns}}$ & $-0.42^{\mathrm{a}}$ & $-0.36^{\mathrm{ns}}$ & $-0.73^{\mathrm{a}}$ & $-0.35^{\mathrm{ns}}$ \\
\hline Co & 10 & 0.98 & & & & & 10 & 0.98 & & & & \\
\hline Mn & 2 & $-0.94^{\mathrm{ns}}$ & $-0.94^{\mathrm{ns}}$ & & $-0.94^{\mathrm{ns}}$ & & 20 & $0.70^{\mathrm{a}}$ & $0.71^{\mathrm{a}}$ & $0.71^{\mathrm{a}}$ & $0.86^{\mathrm{a}}$ & $0.70^{\mathrm{a}}$ \\
\hline $\mathrm{Fe}$ & & & & & & & 4 & $-0.50^{\mathrm{ns}}$ & $-0.83^{\mathrm{ns}}$ & $-0.83^{\mathrm{ns}}$ & $-0.50^{\mathrm{ns}}$ & \\
\hline
\end{tabular}

All p-values $<0.01$ except those indicated with ns, non-significant. Different letters within each row indicate significant differences between correlation coefficients according to Fisher's comparison test at $\mathrm{p}<0.05$. Empty coefficient fields indicate that the correlation model cannot be fitted with variables since the data analyzed were taken from either one plant species, reference source, plant tissue type, or study type only. 
1 Table 4. Correlation coefficients ( $\mathrm{r})$ for the soil-HM concentration ([HM $\left.\left.\mathrm{Hoil}_{\mathrm{s}}\right]\right)$, plant $\mathrm{HM}$ content ( $\mathrm{HM}_{\mathrm{plant}}$, and plant 2 HM concentration ([HM $\left.\left.\mathrm{Hlant}_{\mathrm{p}}\right]\right)$ in relation with the TI. The $\mathrm{r}$ values for raw and fitted coefficients (heavy metal type, $3 \mathrm{r}_{\mathrm{HM}}$; reference, $\mathrm{r}_{\mathrm{r}}$; species, $\mathrm{r}_{\mathrm{s}}$; plant tissue type, $\mathrm{r}_{\mathrm{t}}$; study type, $\mathrm{r}_{\mathrm{st}}$ ) and degrees of freedom $(\mathrm{df})$ are shown.

\begin{tabular}{lccccccc}
\hline Correlation comparison & $\mathrm{df}$ & $\mathrm{r}$ & $\mathrm{r}_{\mathrm{HM}}$ & $\mathrm{r}_{\mathrm{sp}}$ & $\mathrm{r}_{\mathrm{r}}$ & $\mathrm{r}_{\mathrm{t}}$ & $\mathrm{r}_{\mathrm{st}}$ \\
\hline$\left[\mathrm{HM}_{\text {soil }}\right]$ & 236 & $-0.21^{\mathrm{b}}$ & $-0.29^{\mathrm{b}}$ & $-0.49^{\mathrm{a}}$ & $-0.55^{\mathrm{a}}$ & $-0.27^{\mathrm{b}}$ & $-0.24^{\mathrm{b}}$ \\
$\mathrm{HM}_{\text {plant }}$ & 236 & $-0.12^{\mathrm{ns}}$ & $-0.23^{\mathrm{ns}}$ & $-0.44^{\mathrm{a}}$ & $-0.39^{\mathrm{a}}$ & $-0.21^{\mathrm{ns}}$ & $-0.15^{\mathrm{ns}}$ \\
{$\left[\mathrm{HM}_{\text {plant }}\right]$} & 220 & $-0.19^{\mathrm{b}}$ & $-0.32^{\mathrm{b}}$ & $-0.49^{\mathrm{a}}$ & $-0.54^{\mathrm{a}}$ & $-0.24^{\mathrm{b}}$ & $-0.20^{\mathrm{b}}$ \\
\hline
\end{tabular}


SUPPLEMENTARY DATA

Supplement - 25

9 Heavy metals and soil concentration ranges comprised in the meta-analysis.

\begin{tabular}{|c|c|c|}
\hline HM & $\begin{array}{l}\text { soil } \mathrm{HM} \text { range } \\
\left(\mathrm{mg} \mathrm{kg}^{-1} \text { dry }\right. \\
\text { soil) }\end{array}$ & Reference \\
\hline $\mathrm{Zn}$ & $0.2-27413$ & $\begin{array}{l}\text { Audet \& Charest 2006; Ayoub et al 2003; Bi et al. 2003; Barazani et al 2002; Bi et al. 2003; Chen et al. } \\
\text { 2003a, 2004; Cui et al. 2004; Delorme et al. 2001; Freeman et al. 2005; Gildon \& Tinker 1983; } \\
\text { Hammer \& Keller 2002; Kubota \& Takenaka 2003; Li \& Christie 2001; Marchiol et al. 2004a, b; } \\
\text { Mereno et al. 2002; Shen et al. 2002; Wang et al. 2005; Weissenhorn et al. 1995; Wu et al. 2004; Xia } \\
\text { 2004; Yanai et al 2006. }\end{array}$ \\
\hline $\mathrm{Cd}$ & $0.001-770$ & $\begin{array}{l}\text { Ayoub et al 2003; Barazani et al 2002; Chen et al. 2003b, 2004; Citterio et al. 2003; Delorme et al. } \\
\text { 2001; Gildon \& Tinker 1983; Hammer \& Keller 2002; Hutchinson et al. 2000; Kubota \& Takenaka } \\
\text { 2003; Marchiol et al. 2004a, b; Pichtel et al. 2000; Riverra-Becerral et al. 2002; Shen et al. 2002; Wang } \\
\text { et al. 2005; Weissenhorn et al. 1995; Wu et al. 2004; Xia 2004; Yanai et al 2006. }\end{array}$ \\
\hline $\mathrm{Pb}$ & $24-140500$ & $\begin{array}{l}\text { Barazani et al. 2002; Blaylock et al. 1997; Chen et al. 2003b; Cui et al. 2004; Huang et al. 1997; Kubota } \\
\text { \& Takenaka 2003; Marchiol et al. 2004a, b; Mereno et al. 2002; McGrath et al. 1997; Pichtel et al. } \\
\text { 2000; Rydlova \& Vosatka 2003; Shen et al. 2002; Vivas et al. 2003; Wang et al. 2005; Weissenhorn et } \\
\text { al. 1995; Wu et al. 2004; Xiong et al. } 1997 \text {. }\end{array}$ \\
\hline $\mathrm{Cu}$ & $5-1631$ & $\begin{array}{l}\text { Barazani et al. 2002; Gildon \& Tinker 1983; Hammer \& Keller 2002; Jiang \& Wang 2004; Kubota \& } \\
\text { Takenaka 2003; Marchiol et al. 2004a, b; Mereno et al. 2002; McGrath et al 1997; Shen et al. 2002; } \\
\text { Wang et al. 2005; Weissenhorn et al. 1995; Wu et al. 2004; Yanai et al } 2006 .\end{array}$ \\
\hline $\mathrm{Ni}$ & $5-2570$ & $\begin{array}{l}\text { Barazani et al. 2002; Citterio et al. 2003, 2005; Freeman et al. 2005; Gildon \& Tinker 1983; Marchiol et } \\
\text { al. 2004a, b; McGrath et al. 1997; Li et al. 2003. }\end{array}$ \\
\hline $\mathrm{Cr}$ & $18-300$ & Citterio et al. 2003, 2005; Marchiol et al. 2004a, b. \\
\hline $\mathrm{Fe}$ & $3-34$ & Barazani et al. 2002, Kubota \& Takenaka 2003. \\
\hline $\mathrm{Co}$ & $24-37$ & Li et al. 2003. \\
\hline $\mathrm{Mn}$ & $21-114000$ & $\begin{array}{l}\text { Barazani et al. 2002, Kubota \& Takenaka 2003, McGrath et al. 1997; Weissenhorn et al. 1995, Xue et } \\
\text { al. } 2004 .\end{array}$ \\
\hline
\end{tabular}


11 Plants species comprised in the meta-analysis.

\begin{tabular}{|c|c|c|c|}
\hline Species & Reference & Species & Reference \\
\hline Achillea millefolium & Pichtel et al. 2000 & $\begin{array}{l}\text { Pennisetum glaucum } x P \text {. } \\
\text { Purpureum }\end{array}$ & Xia 2004 \\
\hline Aesculus glabra & Pichtel et al. 2000 & Phytolacca acinosa & Xue et al. 2004 \\
\hline Agrostemma githago & Pichtel et al. 2000 & Pisum sativum & $\begin{array}{l}\text { Huang et al. 1997; Riverra-Becerril et al. } \\
2002 .\end{array}$ \\
\hline Agrostis capillaris & Rydlova \& Vosatka 2003 & P. pratense & $\begin{array}{l}\text { Bi et al. 2003, Chen et al. 2003a, Li \& } \\
\text { Christie } 2001\end{array}$ \\
\hline Allium cepa & Gildon \& Tinker 1983 & Platanus occidentalis & Pichtel et al. 2000 \\
\hline Alyssum corsicum & Li et al. 2003 & Potentilla norvegica & Pichtel et al. 2000 \\
\hline Ambrosia artimissifolia & Pichtel et al. 2000 & Raphanus sativus & Chen et al. 2003b; Marchiol et al. 2004a, b \\
\hline Anfropogon virginicus & Pichtel et al. 2000 & Rosa multiflora & Pichtel et al. 2000 \\
\hline Arabis gemmifera & Kubota \& Takenaka 2003 & Sonchus oleraceus & Xiong 1997 \\
\hline Brassica carinata & Marchiol et al. 2004a & Stenataphrum secundatum & Xia 2004 \\
\hline B. juncea & $\begin{array}{l}\text { Blaylock et al. 1997; Cui et al. } \\
\text { 2004; Marchiol et al. 2004a, b; Su } \\
\text { \& Wong 2004; Wu et al. 2004. }\end{array}$ & Taraxacum officinale & Pichtel et al. 2000 \\
\hline B. napus & Marchiol et al. 2004a, b & Thlaspi arvense & Freeman et al. 2005 \\
\hline B. napa & Shen et al. 2002 & T. caerulescens & $\begin{array}{l}\text { Ayoub et al. 2003; Delorme et al. 2001; } \\
\text { Freeman et al. 2005; Hammer \& Keller } \\
\text { 2002; Hutchinson et al. 2000; McGrath et al. } \\
\text { 1997; Yanai et al. 2006. }\end{array}$ \\
\hline B. pekinensis & Mereno et al. 2002 & T. ochroleucum & McGrath et al. 1997 \\
\hline Cannabis sativa & Citterio et al. 2003, 2005. & T. officinale & Ayoub et al. 2003 \\
\hline Elsholtzia splendens & $\begin{array}{l}\text { Jiang \& Yang 2004; Wang et al. } \\
2005\end{array}$ & T. oxyceras & Freeman et al. 2005 \\
\hline Glechoma hederacea & Pichtel et al. 2000 & T. perfoliatum & Freeman et al. 2005 \\
\hline Hordeum vulgare & Ayoub et al. 2003 & T. pratense & Delorme et al. 2001 \\
\hline $\begin{array}{l}\text { Lepidium } \\
\text { heterophyllum }\end{array}$ & Hutchinson et al. 2000 & T. rosulare & Freeman et al. 2005 \\
\hline Medicago lupulina & Pichtel et al. 2000 & Trifolium pratense & Vivas et al. 2003 \\
\hline Mullen verbascum & Pichtel et al. 2000 & Triticum aestivum & $\begin{array}{l}\text { Huang et al. 1997; Shen et al. 2002; Cui et } \\
\text { al. } 2004\end{array}$ \\
\hline Nicotiana glauca & Barazani et al. 2002 & Vetiveria zizanoides & Xia 2004 \\
\hline N. rustica & Audet \& Charest 2006 & Vigna radiata & Shen et al. 2002 \\
\hline Paspalum notanum & Xia 2004 & Zea mays & Chen et al. 2004; Weissenhorn et al. 1995 \\
\hline
\end{tabular}




\section{REFERENCES}

Audet, P., Charest, C., 2006. Effects of AM colonization on "wild tobacco" plants grown in zinccontaminated soil. Mycorrhiza 16, 277-283.

Ayoub, A.S., McGaw, B.A., Shand, C.A., Midwood, A.J., 2003. Phytoavailability of Cd and Zn in soil estimated by stable isotope exchange and chemical extraction. Plant and Soil 252, 291-300.

Barazani, O., Sathiyamoorthy, P., Manandhar, U., Vulkan, R., Golan-Goldhirsh, A., 2002. Heavy metal accumulation by Nicotiana glauca Graham in a solid waste disposal site. Chemosphere 54, 867-872.

Bi, Y.L., Li, X.L., Christie, P., 2003. Influence of early stages of arbuscular mycorrhiza on uptake of zinc and phosphorus by red clover from a low-phosphorus soil amended with zinc and phosphorus. Chemosphere 50, 831-837.

Blaylock, M.J., Salt, D.E., Dushenkov, S., Zakharov, O., Gussman, C., Kapulnik, Y., Ensley, B.D., Raskin, I., 1997. Enhanced accumulation of Pb, in indian mustard by soil applied chelating agents. Environmental Science and Technology 31, 860-865.

Chen, B.D., Li, X.L., Tao, H.Q., Christie, P., Wong, M.H., 2003a. The role of arbuscular mycorrhiza in zinc uptake by red clover growing in a calcareous soil spiked with various quantities of zinc. Chemosphere 50, 839-846.

Chen, Y.X., Lin, Q., Luo, Y.M., He, Y.F., Zhen, S.J., Yu, Y.L., Tian, G.M., Wong, M., $2003 b$. The role of citric acid on the phytoremediation of heavy metal contaminated soil. Chemosphere 50, 807-811. 
Chen, B.D., Liu, Y., Li, X.L., Christie, P., 2004. Uptake of cadmium from an experimentally contaminated calcareous soil by arbuscular mycorrhizal maize (Zea mays L.). Mycorrhiza $14,347-354$.

Citterio, S., Santagostino, A., Furnagalli, P., Prato, N., Ranalli, P., Sgorbati, S., 2003. Heavy metal tolerance and accumulation of $\mathrm{Cd}, \mathrm{Cr}$, and $\mathrm{Ni}$ by Cannabis sativa L. Plant and Soil 256, 243-252.

Cui, Y., Wang, Q., Dong, Y., Li, H., Christie, P., 2004. Enhanced uptake of soil Pb and Zn by Indian mustard and winter wheat following combined soil application of elemental sulphur and EDTA. Plant and Soil 261, 181-188.

Delorme, T.A., Gagliardi, J.V., Angle, J.S., Chaney, R.L., 2001. Influence of the zinc hyperaccumulator Thlaspi caerulescens J. \& C. Presl. and the nonmetal accumulator Trifolium pratense L. on soil microbial populations. Canadian Journal of Microbiology 47, 773-776.

Freeman, J.L., Garcia, D., Kim, D., Hopf, A., Salt, D.E., 2005. Constitutively elevated salicylic acid signals glutathione-mediated nickel tolerance in Thlaspi nickel hyperaccumulators. Plant Physiology 137, 1082-1091.

Gildon, A., Tinker, P.B., 1983. Interactions of vesicular-arbuscular mycorrhizal infection and heavy metals in plants. I. The effects of heavy metals on the development of vesiculararbuscular mycorrhizas. New Phytologist 95, 247-261.

Hammer, D., Keller, C., 2002. Changes in the rhizosphere of metal-accumulating plants evidenced by chemical extractants. Journal of Environmental Quality 31, 1561-1569. 
Huang, J.W., Cunningham, S.D., 1996. Lead phytoextraction: species variation in lead uptake and translocation. New Phytologist 134, 75-84.

Hutchinson, J.J., Young, S.D., McGrath, S.P., West, H.M., Black, C.R., Baker, A.J.M., 2000. Determining uptake of 'non-labile' soil cadmium by Thlaspi caerulescens using isotopic dilution techniques. New Phytologist 146, 453-460.

Jiang, L.Y., Yang, X.E., 2004. Chelators effect on soil Cu extractability and uptake by Elsholtzia splendens. Journal of Zhejiang University Science 5, 450-456.

Kubota, H., Takenaka, C., 2003. Arabis gemmifera is a hyperaccumulator of Cd and Zn. International Journal of Phytoremediation 5, 197-201.

Li, X.L., Christie, P., 2001. Changes in soil solution $\mathrm{Zn}$ and $\mathrm{pH}$ and uptake of $\mathrm{Zn}$ by arbuscular mycorrhizal red clover in Zn-contaminated soil. Chemosphere 42, 201-207.

Li, Y.M., Chaney, R.L., Brewer, E.P., Angle, J.S., Nelkin, J., 2003. Phytoextration of nickel and cobalt by hyperaccumulator Alyssum species grown on nickel-contaminated soils. Environmental Science and Technology 37, 1463-1468.

Marchiol, L., Assolari, S., Sacco, P., Zerbi, G., 2004a. Phytoextraction of heavy metals by canola (Brassica napus) and radish (Raphanus sativus) grown on multicontaminated soil. Environmental Pollution 132, 21-27.

Marchiol, L. Sacco, P., Assolar, S., Zerbi, G., 2004b. Reclamation polluted soil: phytoremediation potential of crop-related Brassica species. Water Air Soil and Pollution $158,345-356$.

McGrath, S.P., Shen, Z.G., Zhao, F.J., 1997. Heavy metal uptake and chemical changes in the rhizosphere of Thlaspi caerulescens and Thlaspi ochroleucum grown in contaminated soils. Plant and Soil 188, 153-159.

Mereno, D.A., Villora, G., Hernández, J., Castilla, N., Romero, L., 2002 Accumulation of Zn, 
$\mathrm{Cd}, \mathrm{Cu}$, and $\mathrm{Pb}$ in Chinese cabbage as influenced by climatic conditions under protected cultivation. Journal of Agricultural and Food Chemistry 50, 1964-1969.

Pichtel, J., Kuroiwa, K., Sawyerr, H.T., 2000. Distribution of Pb, Cd and Ba in soils and plants of two contaminated sites. Environmental Pollution 110, 171-178.

Rydlová, J., Vosátka, M., 2003. Effect of Glomus intraradices isolated from Pb-contaminated soil on $\mathrm{Pb}$ uptake by Agrostis capillaris is changed by its cultivation in a metal-free substrate. Folia Geobotanica 38, 155-165.

Rivera-Becerril, F., Calantzis, C., Turnau, K., Caussanel, J.P., Belimov, A.A., Gianinazzi, S., Strasser, R.J., Gianinazzi-Pearson, V., 2002. Cadmium accumulation and buffering of cadmium-induced stress by arbuscular mycorrhiza in three Pisum sativum L. genotypes. Journal of Experimental Botany 53, 1177-1185.

Shen, Z.G., Li, Z.D., Wang, C.C., Chen, H.M., Chua, H., 2002. Lead phytoextraction from contaminated soil with high-biomass plant species. Journal of Environmental Quality 31, 1893-1900.

Vivas, A., Azcón, R., Biró, B., Barea, J.M., Ruiz-Lozano, J.M., 2003. Influence of bacterial strains isolated from lead-polluted soil and their interactions with arbuscular mycorrhizae on the growth of Trifolium pratense L. under lead toxicity. Canadian Journal of Microbiology 49, 577-588.

Wang, S.H., Tang, Z.M., Yang, H., Lu, B., Li, S.Q., Lu, Y.P., 2004. Copper-induced stress and antioxydative responses in roots of Brassica juncea L. Botanical Bulletin of Academia Sinica 45, 203-212.

Weissenhorn, I., Leyval, C., Belgy, G., Berthelin, J., 1995. Arbuscular mycorrhizal contribution to heavy metal uptake by maize (Zea mays L.) in pot culture with contaminated soil. Mycorrhiza 5, 245-251. 
Wu, L.H., Luo, Y.M., Xing, X.R., Christie, P., 2004. EDTA-enhanced phytoremediation of heavy metal contaminated soil with Indian mustard and associated potential leaching risk. Agriculture Ecosystems and Environment 102, 307-318.

Xia, H.P., 2004. Ecological rehabilitation and phytoremediation with four grasses in oil shale mined land. Chemosphere 54, 345-353.

Xiong, Z.T., 1997. Bioaccumulation and physiological effects of excess lead in a roadside pioneer species Sonchus oleraceus L. Environmental Pollution 93, 275-279.

Xue, S.G., Chen, Y.X., Reeves, R.D., Baker, A.J.M., Lin, Q., Fernando, D.R., 2004. Manganese uptake and accumulation by the hyperaccumulator plant Phytolacca acinosa Roxb. (Phytolaccaceae). Environmental Pollution 131, 393-399.

Yanai, J., Zhao, F.J., McGrath, S.P., Kosaki, T., 2006. Effect of soil characteristics on Cd uptake by the hyperaccumulator Thlaspi caerulescens. Environmental Pollution 139, 167-175. 